\section{Factors associated with gestational weight gain in pregnant women in Rio de Janeiro, Brazil, 2008}

\author{
Fatores associados ao ganho de peso gestacional \\ entre gestantes do Município do Rio de Janeiro, \\ Brasil, 2008
}

\author{
Factores asociados con el aumento de peso \\ gestacional en mujeres embarazadas en el \\ municipio de Río de Janeiro, Brasil, 2008
}

Ana Claudia Santos Amaral Fraga 1,2 Mariza Miranda Theme Filha ${ }^{2}$

\footnotetext{
1 Instituto de Pesquisa Clínica Evandro Chagas, Fundação Oswaldo Cruz, Rio de Janeiro, Brasil.

2 Escola Nacional de Saúde Pública Sergio Arouca, Fundação Oswaldo Cruz, Rio de Janeiro, Brasil.

Correspondence A. C. S. A. Fraga Instituto de Pesquisa Clínica Evandro Chagas, Fundação Oswaldo Cruz.

Rua Comendador Francisco Baroni 738, Nova Iguaçu, $R$ 26250-070, Brasil.

ana.amaral@ipec.fiocruz.br
}

\begin{abstract}
Inadequate weight gain during pregnancy is an important predictor of complications for the mother and infant. This cross-sectional study as sessed factors associated with inadequate weight gain among women in the third trimester of pregnancy who received prenatal care under the Brazilian Unified National Health System (SUS) in the city of Rio de Janeiro, Brazil, from November 2007 to July 2008. A total of 1,079 preg nant women were interviewed, and adequacy of weight gain was obtained by calculating weight gain as recommended by the U.S. Institute of Medicine. Social, demographic, and obstetric factors were analyzed as independent variables. A multinomial logistic regression model was used, and pregnant women with weight gain below or above the recommended levels were compared to those with adequate weight gain. Low schooling was associated with insufficient weight gain, while excessive gain was observed in women with hypertension and pre-gestational underweight, overweight, and obesity. Nutritional assessment during prenatal care is essential, and interventions should target cases of inadequate weight gain in order to prevent complications for the mother and infant.
\end{abstract}

Weight Gain; Pregnancy; Pregnant Women; Nutritional Status

\section{Resumo}

Inadequações do ganho de peso na gestação são importantes preditores de complicações para o binômio mãe-bebê. Este estudo seccional avaliou os fatores associados à inadequação do ganho de peso entre as gestantes no 30 trimestre, que realizaram pré-natal na rede do Sistema Único de Saúde (SUS) do Município do Rio de Janeiro, Brasil, de novembro de 2007 a julho de 2008. Foram entrevistadas 1.079 gestantes e a adequação do ganho de peso foi obtida pelo cálculo da quantidade de ganho de peso recomendada pelo Instituto de Medicina dos Estados Unidos. Fatores sociodemográficos e obstétricos foram analisados como variáveis independentes. Utilizou-se modelo de regressão logística multinomial e as gestantes com ganho de peso abaixo ou acima das recomendações foram comparadas àquelas com ganho de peso adequado. Baixa escolaridade associou-se com ganho de peso insuficiente e ganho de peso excessivo foi observado entre as mulheres com pressão arterial elevada e com estado nutricional pré-gestacional de baixo peso, sobrepeso e obesidade. A avaliação nutricional no pré-natal é fundamental, e as intervenções devem ser dirigidas para os casos de ganho de peso inadequado, de forma a prevenir complicações para a mãe e o bebê.

Ganho de Peso; Gravidez; Gestantes; Estado Nutricional 


\section{Introduction}

Weight gain during pregnancy is a complex biological phenomenon and is one of the factors that support fetal growth and development. Its components include the products of the conception (fetus, placenta, and amniotic fluid), accumulation of maternal tissues, and maternal reserve body fat 1 .

The Brazilian Ministry of Health currently recommends weight gain of 11.5 to $16.0 \mathrm{~kg}$ for women with adequate pre-gestational body mass index (BMI), 12.5 to $18.0 \mathrm{~kg}$ for those with low BMI, 7.0 to $11.5 \mathrm{~kg}$ for women with overweight, and 5.0 to $9.0 \mathrm{~kg}$ for women with obesity, based on recommendations by the U.S. Institute of Medicine 1,2.

Weight gain during pregnancy is a widely used anthropometric indicator, both in health services and in research on maternal-fetal health, since it bears a direct influence on pregnancy outcomes 3 . Studies have reported an association between insufficient weight gain in pregnancy and increased risk of low birth weight, intrauterine growth restriction, and prematurity 4,5 . Meanwhile, excessive weight gain has been associated with increased incidence of diabetes mellitus and gestational hypertension, cesarean delivery, fetal macrosomia, perinatal morbidity and mortality, postpartum weight retention, and childhood obesity 6,7,8,9,10.

Various risk factors for insufficient or excessive weight gain have been reported in the literature, such as maternal age, intervals between gestations and deliveries, co-morbidities, lifestyle, pre-gestational nutritional status, and family violence $1,11,1,13,14,15,16$.

The identification of factors that act on gestational weight gain and its alterations is indispensable for screening pregnant women at risk, thus allowing timely and effective interventions according to each case. The current study aimed to assess factors associated with gestational weight gain in women during the third trimester of pregnancy and receiving prenatal care under the Brazilian Unified National Health System (SUS) in the city of Rio de Janeiro, Brazil.

\section{Methodology}

\section{Data source and study population}

This study is part of the project entitled Prenatal Care Quality Assessment under the Unified National Health System in the City of Rio de Janeiro, a cross-sectional study on prenatal care in pregnant women treated at health services under the
SUS network from November 2007 to July 2008. The sample design involved a two-stage cluster, the first of which selected health services providing low-risk prenatal care and the second of which selected the pregnant women. The health services were stratified as primary care units (UBS), hospitals/maternity wards, birthing centers, and family health strategy units (USF). The study included healthcare units with a monthly mean of more than 80 prenatal visits, except for the USF, which were selected by prioritizing the units installed up to six months before the beginning of data collection, having more than three health teams, and not located in violent areas.

The second stage selected the pregnant women. Inclusion was based on treatment at the above-mentioned health services, regardless of gestational age or place of residence. The women were selected systematically in the same order as they left their prenatal visits, until completing the scheduled sample for each health service.

The sample size was determined according to the outcome "adequate prenatal care", estimated at $50 \% 17,5 \%$ significance, and $2.5 \%$ bilateral margin of error. A correction was made for a finite population and design effect, estimated at 1.5. The sample allocation was proportional to the number of prenatal visits in each stratum, based on information for 2006 from the Rio de Janeiro Municipal Health Secretariat.

The total sample calculation was 2,417 pregnant women, and the number of interviews for each stratum was divided by the number of sampled health units. The study analyzed 2,353 interviews, excluding those lacking the standard prenatal card or that failed to record the woman's gestational age at the time of the interview.

The current study included all the pregnant women $(1,168)$ with gestational age greater than or equal to 28 weeks at the time of the interview. This strategy is based on the fact that weight gain varies over the course of pregnancy, with greater gain as gestational age increases, especially in the third trimester. In addition, during the first trimester of pregnancy (up to 14 weeks), weight gain varies little and may even be negative. A total of 89 women $(7.6 \%)$ were excluded for lack of information on pre-gestational weight and current weight, and the final sample included 1,079 pregnant women.

Post-hoc sample size calculations were performed, considering a prevalence of $35 \%$ of women who gained more weight than recommended in the public healthcare sector 14 and $5 \%$ level of significance. The sample of pregnant women in the third trimester $(1,168)$ showed a power of $80 \%$ to detect differences of at least $7 \%$. 


\section{Study variables}

\section{- Dependent variable}

Adequacy of weight gain during pregnancy (the outcome variable) was defined according to guidelines by the U.S. Institute of Medicine 1, where for each pre-gestational nutritional status there is an acceptable range in weight gain. BMI was calculated by dividing pre-gestational weight by height squared, using pre-gestational weight and height as reported by the woman.

Due to the high proportion (26\%) of missing values for height, data imputation was used. This process involves the use of an ancillary variable (age bracket) capable of predicting the target variable, using a logistic regression model developed by Silva 18. Imputation procedures were performed in the R environment and language, version 2.6.1 (The R Foundation for Statistical Computing, Vienna, Austria; http://www.r-proj ect.org), using the rpart library.

Due to the specificities of anthropometric assessment of pregnant adolescents, the study used the classification of pre-gestational BMI recommended by Saunders et al. ${ }^{19}$, adopting the cutoff points for adolescents recommended by the Brazilian Ministry of Health 2.

After classification of the pregnant women's nutritional status, the ideal weight gain was calculated as recommended by the U.S. Institute of Medicine 1. This set a weight gain of 0.5 to $2.0 \mathrm{~kg}$ in the first trimester of pregnancy, and in the second and third trimesters a weekly weight gain according to pre-gestational weight, varying from $0.44-0.58 \mathrm{~kg}$ (for underweight pregnant women) to $0.35-0.50 \mathrm{~kg}$ (pregnant women with adequate weight), $0.23-0.33 \mathrm{~kg}$ (overweight pregnant women), and 0.17-0.27kg (pregnant women with obesity).

Since the sample included women with different gestational ages and interviewed only once, there was no information on total gestational weight gain, the most widely used indicator in studies assessing weight gain in pregnancy. Thus, weight gain adequacy was calculated according to the pregnant woman's gestational age at the time of the interview. For each gestational age and pre-gestational nutritional status, the minimum and maximum weight gains were calculated as recommended by the U.S. Institute of Medicine 1. For example, for a woman classified as having low pre-gestational weight and in her $30^{\text {th }}$ week of pregnancy, the minimum recommended weight gain was calculated as $[0.5+$ $\left.\left(0.44^{*} 17\right)\right]$. Likewise, the maximum weight gain was calculated as $[2.0+(0.58 * 17)]$.
Weight gain for each pregnant woman was calculated by subtracting pre-gestational weight from the weight recorded on the day of the interview. This value was compared to the recommended weight gain for the woman's gestational age, and the pregnant women were classified as having insufficient, adequate, or excessive weigh gain, according to whether the weight gain was below or above the ideal gain for each category of initial nutritional status, taking the woman's gestational age into consideration ${ }^{1}$.

\section{- Independent variables}

Gestational weight gain was analyzed in relation to social and demographic variables: maternal age ( $<20,20$ to 34 , and $\geq 35$ years), self-reported color/race (white, Asian, black, mixed-race, and indigenous), schooling ( $\leq 7$ years; 8 to 10 years, $\geq 11$ years), economic class as defined by the Brazilian Association of Public Opinion Polls (ABEP) 21 in five categories (A to E), and marital status (married or living with partner vs. not); obstetric: childbirth history (nulliparous; 1 to 2 deliveries; 3 or more deliveries), adequacy of the number of prenatal visits for gestational age (adequate/inadequate); clinical: hypertension (yes/no) and diabetes mellitus (yes/no); lifestyle: smoking during the pregnancy (yes/no); nutritional: pre-gestational nutritional status (underweight, adequate, overweight, obesity), received nutritional counseling during prenatal care (yes/no), and type of health professional that provided the nutritional counseling (nutritionist, nurse, physician, or other).

Hypertension and gestational diabetes were diagnosed on the basis of information from the woman's prenatal card, complemented when necessary with data from the interview. Hypertension was defined as a measurement of systolic pressure greater than or equal to $140 \mathrm{mmHg}$ and diastolic pressure greater than or equal to $90 \mathrm{mmHg}$ during any consultation, or a history of chronic arterial hypertension. Classification of gestational diabetes was based on history of diabetes in a previous pregnancy, diagnosis of diabetes during the current pregnancy, fasting blood glucose $>126$ (in two tests), or an altered oral glucose tolerance test during the current pregnancy. Data for both conditions were analyzed by independent obstetricians, who classified the pregnant women according to the available information, and discrepancies were resolved by consensus.

As for the health professional that provided nutritional counseling, this variable was recoded considered the number of times each professional category was mentioned. The informa- 
tion was missing from fewer than $10 \%$ of the prenatal cards.

Adequacy of prenatal care was calculated according to the guidelines of the Brazilian Ministry of Health's Program for Humanization of Prenatal Care and Childbirth (PHPN) 20, considering the number of prenatal visits in relation to the woman's gestational age at the time of the interview. Thus, women with gestational age from 28 to 33 weeks and fewer than 4 visits were classified as having inadequate prenatal care, vs. 4 or more visits as adequate prenatal care. Women with gestational age from 34 to 37 weeks and fewer than 5 visits were classified as having inadequate prenatal care, vs. those with 5 or more visits as adequate prenatal care. Finally, women with gestational age greater than 37 weeks and fewer than 6 visits were classified as having inadequate prenatal care, vs. those with 6 or more visits as adequate prenatal care.

Economic class was defined according to the criteria used by the ABEP 21, which estimates the purchasing power of urban individuals and families, based on household assets and the head-ofhousehold's schooling. The socioeconomic classes varied from A to E, with A as the highest. Due to the small number of interviewees from socioeconomic classes $B$ and $E$, this variable was grouped into only two categories $(B+C ; D+E)$. No women were classified as socioeconomic class A. Due to the small number of women that classified themselves as Asian, indigenous, and black, the color/ race variable was grouped in two categories: white (white plus Asian) and non-white (black, mixed-race, and indigenous).

\section{Statistical analysis}

Bivariate and multivariate analyses were conducted using a multinomial logistic regression model, since the response variable consisted of three categories. In this study, pregnant women with insufficient or excessive weight gain were compared to the reference category (adequate weight gain). Variables with statistical significance at $20 \%$ in the Wald test were included in the multivariate analysis. This stage also took into consideration the explanatory power of some factors already identified as important in the literature, even when they failed to reach the defined statistical significance.

In the multivariate analysis, the saturated model was elaborated with all the variables identified in the bivariate analysis. Elimination was conducted using the backward stepwise methodology. The criterion for variables to remain in the final model was statistical significance at $5 \%$.
Since the study involved complex sampling, each element in the sample was weighted by the inverse of the probability of its selection and calibrated to reestablish the known distribution of prenatal visits. Data analysis used SPSS, version 16.0 (SPSS Inc., Chicago, USA), using the module for adjusting complex samples.

The research project was approved by the Ethics Research Committee of the Sergio Arouca National School of Public Health, Oswaldo Cruz Foundation (ENSP/Fiocruz; CAAE 0160.0.031.000-11) and complied with all the provisions of Ruling no. 196/96 of the Brazilian National Health Council.

\section{Results}

Mean age was 24.5 years, with standard deviation (SD) of \pm 6.1 (minimum and maximum of 13 and 44 years, respectively). Adolescents represented $22.3 \%$ of the total sample. Mean schooling was 8.6 years $(\mathrm{SD} \pm 2.6)$. Most of the women belonged to economic classification B + C (74.5\%), and most were married or living with a partner $(78.4 \%)$. As for the number of prenatal visits, more than $70 \%$ of the pregnant women were classified as having adequate prenatal care for gestational age, while approximately half of the sample had their pre-gestational nutritional status classified as adequate (Table 1).

Mean weight gain was $12.3 \mathrm{~kg}$, and women with obesity at the beginning of the pregnancy gained less weight $(9.8 \mathrm{~kg} \pm 7.9)$ than those with adequate weight $(13.5 \mathrm{~kg} \pm 6.1)$, low weight $(12.8 \mathrm{~kg} \pm 6.0)$, or overweight $(12.1 \mathrm{~kg} \pm 6.9)$. Fewer than $30 \%$ of the sample displayed adequate weight gain for gestational age, while nearly $50 \%$ of the pregnant women gained more weight than recommended.

The variables with statistical significance at $20 \%$ were age bracket, schooling, married/living with partner, socioeconomic class, adequacy of number of prenatal visits, having received nutritional counseling during prenatal care, type of health professional providing nutritional counseling, hypertension, and pre-gestational nutritional status. All these variables were eligible for the multivariate analysis and were thus included in the saturated model (Table 2).

After removing variables using the backward stepwise technique, the final model for excessive weight gain included all the categories of pre-gestational nutritional status, with odds ratios (OR) of 1.88 (95\%CI: 1.02-3.48) for underweight, 4.06 (95\%CI: 1.95-8.43) for overweight, and 5.86 (95\%CI: 2.45-14.02) for obesity. Although the association between hypertension 
Table 1

General characteristics of a sample of 1,079 pregnant women. Rio de Janeiro, Brazil, 2008-2009.

\begin{tabular}{|c|c|c|}
\hline \multirow[t]{2}{*}{ Variables } & \multicolumn{2}{|c|}{ Study population } \\
\hline & $\mathrm{n}$ & $\%$ \\
\hline \multicolumn{3}{|l|}{ Age bracket (years) } \\
\hline$<20$ & 241 & 22.3 \\
\hline $20-34$ & 754 & 69.9 \\
\hline$\geq 35$ & 84 & 7.8 \\
\hline \multicolumn{3}{|c|}{ Distribution of gestational age in third trimester (weeks) } \\
\hline$\geq 28$ and $\leq 32$ & 397 & 36.8 \\
\hline$\geq 33$ and $\leq 37$ & 486 & 45.0 \\
\hline$\geq 38$ and $\leq 42$ & 196 & 18.2 \\
\hline \multicolumn{3}{|l|}{ Race/Color } \\
\hline White & 280 & 25.9 \\
\hline Non-white & 799 & 74.1 \\
\hline \multicolumn{3}{|l|}{ Economic class } \\
\hline$B+C$ & 804 & 74.5 \\
\hline$D+E$ & 275 & 25.5 \\
\hline \multicolumn{3}{|c|}{ Married/Living with partner } \\
\hline Yes & 846 & 78.4 \\
\hline No & 233 & 21.6 \\
\hline \multicolumn{3}{|l|}{ Schooling (years) } \\
\hline$\leq 7$ & 367 & 34.0 \\
\hline $8-10$ & 390 & 36.1 \\
\hline$\geq 11$ & 322 & 29.8 \\
\hline \multicolumn{3}{|l|}{ Childbirth history } \\
\hline Nulliparous & 397 & 36.8 \\
\hline $1-2$ & 477 & 44.2 \\
\hline$\geq 3$ & 170 & 15.8 \\
\hline Information missing & 35 & 3.2 \\
\hline \multicolumn{3}{|l|}{ Hypertension } \\
\hline Yes & 108 & 10.0 \\
\hline No & 967 & 89.6 \\
\hline Information missing & 4 & 0.4 \\
\hline \multicolumn{3}{|l|}{ Diabetes mellitus } \\
\hline Yes & 17 & 1.6 \\
\hline No & 432 & 40.0 \\
\hline Information missing & 630 & 58.4 \\
\hline \multicolumn{3}{|l|}{ Smoker } \\
\hline Yes & 302 & 28.0 \\
\hline No & 55 & 5.1 \\
\hline Information missing & 722 & 66.9 \\
\hline \multicolumn{3}{|l|}{ Number of prenatal visits } \\
\hline Adequate & 816 & 75.6 \\
\hline Inadequate & 263 & 24.4 \\
\hline \multicolumn{3}{|c|}{ Received nutritional counseling } \\
\hline Yes & 847 & 78.5 \\
\hline No & 230 & 21.3 \\
\hline
\end{tabular}

(continue) 
Table 1 (continued)

\begin{tabular}{lcc}
\hline Variables & Study population & $\%$ \\
& $\mathbf{n}$ & \\
\hline Professional that provided nutritional counseling & & 17.4 \\
$\quad$ Nutritionist & 188 & 23.2 \\
Nurse & 250 & 45.8 \\
Physician & 494 & 1.1 \\
Other & 12 & 12.5 \\
Information missing & 135 & \\
Pre-gestational BMI (kg/m2) & & 11.9 \\
Underweight & 128 & 54.1 \\
Adequate & 584 & 20.2 \\
Overweight & 218 & 13.8 \\
Obese & 149 & \\
Gestational weight gain & & 23.1 \\
Insufficient & 249 & 27.5 \\
Adequate & 297 & 48.9 \\
Excessive & 528 & 0.5 \\
Information missing & 5 & \\
\hline
\end{tabular}

BMI: body mass index.

Table 2

Factors associated with weight gain in pregnancy. Rio de Janeiro, Brazil, 2008-2009.

\begin{tabular}{|c|c|c|c|c|c|c|}
\hline \multirow[t]{3}{*}{ Variables } & \multicolumn{6}{|c|}{ Weight gain } \\
\hline & \multicolumn{3}{|c|}{ Insufficient } & \multicolumn{3}{|c|}{ Excessive } \\
\hline & OR & $95 \% \mathrm{Cl}$ & p-value & OR & $95 \% \mathrm{Cl}$ & $p$-value \\
\hline \multicolumn{7}{|c|}{ Age bracket (years) } \\
\hline$<20$ & 1.41 & $0.86-2.31$ & 0.163 & 0.89 & $0.57-1.38$ & 0.584 \\
\hline $20-34$ & 1.00 & & & 1.00 & & \\
\hline$\geq 35$ & 1.70 & $0.86-3.36$ & 0.124 & 1.42 & $0.81-2.52$ & 0.216 \\
\hline \multicolumn{7}{|l|}{ Race/Color } \\
\hline White & 1.00 & & & 1.00 & & \\
\hline Non-white & 1.01 & $0.74-1.36$ & 0.96 & 1.258 & $0.874-1.811$ & 0.210 \\
\hline \multicolumn{7}{|c|}{ Schooling (years) } \\
\hline$\leq 7$ & 0.50 & $0.33-0.76$ & 0.002 & 0.94 & $0.55-1.61$ & 0.817 \\
\hline $8-10$ & 0.74 & $0.47-1.18$ & 0.197 & 0.76 & $0.51-1.12$ & 0.161 \\
\hline$\geq 11$ & 1.00 & & & 1.00 & & \\
\hline \multicolumn{7}{|c|}{ Childbirth history } \\
\hline Nulliparous & 1.00 & & & 1.00 & & \\
\hline $1-2$ & 0.93 & $0.62-1.38$ & 0.70 & 1.08 & $0.78-1.48$ & 0.642 \\
\hline$\geq 3$ & 1.44 & $0.85-2.44$ & 0.17 & 1.49 & $0.88-2.53$ & 0.132 \\
\hline \multicolumn{7}{|c|}{ Number of prenatal visits } \\
\hline Adequate & 1.00 & & & 1.00 & & \\
\hline Inadequate & 1.44 & $0.94-2.22$ & 0.093 & 0.93 & $0.68-1.26$ & 0.634 \\
\hline \multicolumn{7}{|c|}{ Nutritional counseling } \\
\hline Yes & 1.00 & & & 1.00 & & \\
\hline No & 0.75 & $0.50-1.12$ & 0.157 & 1.20 & $0.80-1.79$ & 0.378 \\
\hline
\end{tabular}




\begin{tabular}{|c|c|c|c|c|c|c|}
\hline \multirow[t]{3}{*}{ Variables } & \multicolumn{6}{|c|}{ Weight gain } \\
\hline & \multicolumn{3}{|c|}{ Insufficient } & \multicolumn{3}{|c|}{ Excessive } \\
\hline & OR & $95 \% \mathrm{Cl}$ & p-value & OR & $95 \% \mathrm{Cl}$ & $\mathrm{p}$-value \\
\hline \multicolumn{7}{|l|}{ Economic class } \\
\hline$B+C$ & 1.00 & & & 1.00 & & \\
\hline$D+E$ & 1.23 & $0.85-1.79$ & 0.26 & 0.77 & $0.57-1.03$ & 0.081 \\
\hline \multicolumn{7}{|c|}{ Married/Living with partner } \\
\hline Yes & 1.00 & & & 1.00 & & \\
\hline No & 0.81 & $0.49-1.33$ & 0.40 & 0.67 & $0.45-0.98$ & 0.041 \\
\hline \multicolumn{7}{|c|}{ Professional that provided } \\
\hline \multicolumn{7}{|c|}{ nutritional counseling } \\
\hline Nutritionist & 1.00 & & & 1.00 & & \\
\hline Nurse & 1.71 & $1.04-2.81$ & 0.034 & 0.94 & $0.55-1.61$ & 0.832 \\
\hline Physician & 1.42 & $0.86-2.34$ & 0.168 & 0.78 & $0.45-1.34$ & 0.354 \\
\hline Other & 0.66 & $0.12-3.54$ & 0.615 & 0.47 & $0.10-2.22$ & 0.328 \\
\hline \multicolumn{7}{|l|}{ Hypertension } \\
\hline Yes & 0.68 & $0.25-1.87$ & 0.45 & 2.52 & $1.35-4.70$ & 0.005 \\
\hline No & 1.00 & & & 1.00 & & \\
\hline \multicolumn{7}{|l|}{ Diabetes mellitus } \\
\hline Yes & 0.55 & $0.13-2.32$ & 0.41 & 0.83 & $0.27-2.53$ & 0.735 \\
\hline No & 1.00 & & & 1.00 & & \\
\hline \multicolumn{7}{|l|}{ Smoker } \\
\hline Yes & 0.841 & $0.33-2.14$ & 0.709 & 1.18 & $0.52-2.65$ & 0.685 \\
\hline No & 1.00 & & & 1.00 & & \\
\hline \multicolumn{7}{|c|}{ Pre-gestational BMI (kg/m²) } \\
\hline Underweight & 1.32 & $0.68-2.55$ & 0.404 & 1.88 & $0.99-3.55$ & 0.051 \\
\hline Adequate & 1.00 & & & 1.00 & & \\
\hline Overweight & 1.07 & $0.55-2.08$ & 0.838 & 4.20 & $1.98-8.94$ & 0.000 \\
\hline Obese & 1.93 & $0.82-4.58$ & 0.130 & 6.38 & $2.75-14.81$ & 0.000 \\
\hline
\end{tabular}

BMI: body mass index.

and excessive weight gain was not statistically significant (OR = 1.88; 95\%CI: 0.98-3.61), it was kept in the final model due to its relevance for the outcome variable. Schooling was the only variable that showed a significant and inverse relationship with insufficient weight gain (OR = 0.48; 95\%CI: 0.33-0.70) (Table 3).

\section{Discussion}

The mean gestational weight gain of $12.3 \mathrm{~kg}$ was higher than reported by Melo et al. 5 when monitoring a cohort of 115 pregnant women treated in the Family Health Program in Campina Grande, Paraíba State, Brazil, with a mean total weight gain of $10.3 \mathrm{~kg}$. Meanwhile, Drehmer et al. ${ }^{13}$, in a cohort of 780 pregnant women from two cities in Rio Grande do Sul State, Brazil, found a mean weight gain of $13.9 \mathrm{~kg}$ for the total gestational period. These differences in total weight gain may partly represent the specific nutritional profiles of different regions of Brazil, already identified in other studies on Brazilian women 22,23. Importantly, however, the current study sample consisted of women at various moments in the third trimester of pregnancy, which may have underestimated the mean weight gain.

Fewer than $30 \%$ of the women showed adequate weight gain for gestational age. The proportion found in this study is lower (but close to) that reported in other Brazilian studies that considered weight gain for the entire gestational period, ranging from $30 \%$ to $40 \%$ of adequacy in weight gain 24,25 . In the current study, nearly $50 \%$ of the women gained more weight than recommended, even not having completed the entire gestational period. This is worrisome, given the risk associated with excessive gestational weight gain for the mother and infant 9,10,26. Nucci et al. 24 found $29.2 \%$ of weight gain above the limit recommended by the U.S. Institute of Medicine 
Final multinomial logistic regression model for adequacy of gestational weight gain. Rio de Janeiro, Brazil, 2008-2009.

\begin{tabular}{|c|c|c|c|c|c|c|}
\hline \multirow[t]{3}{*}{ Variables } & \multicolumn{6}{|c|}{ Gestational weight gain } \\
\hline & \multicolumn{3}{|c|}{ Insufficient } & \multicolumn{3}{|c|}{ Excessive } \\
\hline & OR & $95 \% \mathrm{Cl}$ & $\mathrm{p}$-value & OR & $95 \% \mathrm{Cl}$ & p-value \\
\hline \multicolumn{7}{|l|}{ Schooling (years) } \\
\hline$\leq 7$ & 0.48 & $0.33-0.70$ & 0.000 & 0.86 & $0.12-1.45$ & 0.561 \\
\hline $8-10$ & 0.74 & $0.47-1.16$ & 0.181 & 0.71 & $0.46-1.08$ & 0.106 \\
\hline$\geq 11$ & 1.00 & & & 1.00 & & \\
\hline \multicolumn{7}{|l|}{ Hypertension } \\
\hline Yes & 0.59 & $0.21-1.64$ & 0.307 & 1.88 & $0.98-3.61$ & 0.059 \\
\hline No & 1.00 & & & 1.00 & & \\
\hline \multicolumn{7}{|c|}{ Pre-gestational BMI (kg/m²) } \\
\hline Underweight & 1.31 & $0.69-2.45$ & 0.396 & 1.88 & $1.02-3.48$ & 0.045 \\
\hline Adequate & 1.00 & & & 1.00 & & \\
\hline Overweight & 1.17 & $0.60-2.27$ & 0.630 & 4.06 & $1.95-8.43$ & 0.000 \\
\hline Obese & 2.19 & $0.97-4.94$ & 0.058 & 5.86 & $2.45-14.02$ & 0.000 \\
\hline
\end{tabular}

BMI: body mass index.

for the entire gestational period in a study on pregnant women from six State capitals of Brazil and monitored from 1991 to 1995.

In the final model, pre-gestational nutritional status, hypertension, and schooling were the variables associated with inadequate gestational weight gain. The data suggest that women who enter pregnancy with overweight or obesity show higher odds of excessive weight gain during pregnancy. This is well-documented in the literature and corroborates findings from other Brazilian studies 9,14. Meanwhile, no statistically significant association was observed between low pregestational weight and insufficient weight gain during pregnancy, a finding also reported in other studies 9,13 .

Attention should be called to the higher odds of excessive weight gain in the group of women who entered pregnancy with a nutritional diagnosis of underweight. One possible explanation could be the change in eating patterns in the Brazilian population, with an increase in the consumption of fat (especially animal fat), sugar, and processed foods and a decrease in the intake of complex carbohydrates and fiber, or the socalled "Western diet" 27.

The study also showed higher odds of excessive weight gain in pregnant women with hypertension, as found in other studies 16,28. The small number of pregnant women with a diagnosis of hypertension probably explains why this variable failed to reach statistical significance, although it was kept in the final model due to its clinical and epidemiological importance.
Hypertensive complications in pregnancy (preeclampsia and eclampsia) are serious public health problems, among the leading causes of maternal and fetal morbidity and mortality 15 and also appear to be associated with pre-gestational nutritional status 29,30 . In this context, prenatal care is used as an indicator of the quality of care provided to the mother and infant, controlling risk factors potentially associated with pregnancy and implementing adequate interventions. Strategies for prevention and clinical management of diseases, immunization screening to identify high-risk pregnancies, and other measures aim to prevent maternal-child morbidity and mortality 17 .

No statistically significant association was found between inadequate gestational weight gain and diabetes. This may be due to the low proportion of the disease in the study sample (1.6\%).

The direction of the association between schooling and deviations from adequate weight gain reported in the international literature differ from the current study's findings. According to a study in the United States in 1992, weight gain less than $7.3 \mathrm{~kg}$ is nearly three times more common in women with little schooling when compared to those with more than 16 years of schooling 11. Meanwhile, women with more schooling have higher odds of weight gain above the recommended level 14,16,31. Low schooling may indirectly reflect limited purchasing power and access to foods, or the choice of foods with low nutritional value and high calorie content. Our 
study showed that women with lower schooling ( $<7$ years) had lower odds of insufficient weight gain in pregnancy $(\mathrm{OR}=0.48)$.

These findings may be associated with the choice of unhealthy eating patterns, as observed by Coelho 32 in her study on pregnant women treated in the SUS in Rio de Janeiro. The study identified four eating patterns during pregnancy, two considered healthier (prudent and traditional) and the other two consisting basically of processed foods, with lower nutritional value and higher calorie content (mixed and snacks). The mixed pattern was associated with lower schooling. Brazilian data thus suggest that the choice of processed foods, with large amounts of saturated fat, trans fat, dyes, and other substances, may influence gestational weight gain in women with less schooling.

Associations between age and inadequate weight gain during pregnancy have also been found. According to some studies, older pregnant women show higher odds of insufficient weight gain, while younger pregnant women have higher odds of excessive weight gain 1,9,11,13,33. The findings in our sample showed no association between age bracket and inadequate gestational weight gain.

Based on the guidelines of the PHPN 20, the number of prenatal visits was considered adequate for most of the sample. Prenatal coverage has expanded considerably in Brazil. For pregnant women with 7 or more prenatal visits, there was an increase in coverage from $22.3 \%$ in 1995 to $57.9 \%$ in 2009 23. Despite the quantitative increase in prenatal visits supplied to these women, Brazilian studies have shown inequalities in the care provided, especially in relation to socioeconomic status 17 , as well as important flaws in the control of some sexually transmissible diseases (HIV and syphilis) ${ }^{34}$.

Despite the crucial role of nutrition in the prevention of a major portion of diseases in all life phases, and particularly the importance of follow-up during the entire gestational period, coverage of nutritional counseling offered to pregnant women failed to reach $80 \%$ of all the women interviewed. Of those that reported having received nutritional counseling, fewer than $20 \%$ had received such orientation from a professional nutritionist. Our study's data suggest that both nutritional counseling and the inclusion of nutritionists in the prenatal process are falling short of the guidelines and needs for dealing with Brazil's epidemiological reality. According to a ruling by the Brazilian Ministry of Health, States and Municipalities should guarantee the assessment and monitoring of all pregnant women's nutritional status in the health services through the Food and Nutritional Surveillance System (SISVAN) 15.

Weight gain during pregnancy is a modifiable factor that can be controlled through adequate prenatal follow-up. Such monitoring facilitates early identification of pregnant women at nutritional risk and allows timely measures for relevant nutritional counseling 35 . Thus, pregnant women with weight gain above or below the guidelines are identified as target groups for the necessary preventive measures and interventions, aimed at improving the care provided to these women. Surveillance of these nutritional states can generate information to back the implementation of more effective health policies and actions 36 .

Early detection of women with a nutritional diagnosis of low pre-gestational weight is important and allows timely assistance and monitoring for these pregnant women. Women who enter pregnancy with under-nutrition are more susceptible to infections (of the digestive, respiratory, and urinary tracts), which can lead to unfavorable systemic repercussions (anemia, anorexia, weight loss), further aggravating their nutritional status 36 . In addition, under-nutrition is associated with higher odds of low birth weight newborns, with negative future consequences for the infant's development 5 .

Finally, excessive weight gain has appeared clearly in numerous Brazilian 5,13,14,37 and international studies 33,38 . The current study confirms this reality, with higher odds of excessive gain for all categories of pre-gestational nutritional status, including for women entering pregnancy with a nutritional diagnosis of underweight. This is a worrisome factor, to the extent that excessive weight gain (as discussed previously) leads to unfavorable short, medium, and long-term outcomes for the mother and fetus.

The associations revealed by the current study's findings differ from those in other Brazilian and international studies, especially in relation to the lower odds of insufficient weight gain in pregnant women with less schooling and higher odds of excessive weight gain in women entering pregnancy with underweight. Changes in eating patterns with the inclusion of foods with lower nutritional value and higher calorie content, growing consumption of processed foods, fast foods, soft drinks, and others particularly interfere in the country's nutritional profile and can partially explain these associations. This pattern is no different in pregnant women in the country, and should be vigorously discouraged due to its potential negative implications for gestational outcomes.

Some methodological limitations need to be mentioned. The pregnant women were inter- 
viewed only once during their prenatal care and presented different gestational ages, so that it was not possible to calculate total gestational weight gain, the, principal indicator used in studies on this topic. The study attempted to avert this situation by only including women in the third trimester of pregnancy, although weight gain in this period can vary considerably. Meanwhile, the high percentage of pregnant women with important deviations in weight gain during pregnancy and with widely diverse gestational ages that comprise the third trimester require reflection on the quality of care for these women.

\section{Resumen}

El aumento inadecuado de peso durante el embarazo es un importante predictor de complicaciones para la madre y el bebé. Este estudio seccional evaluó los factores asociados al inadecuado aumento de peso entre

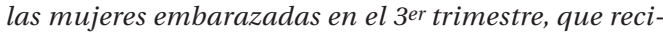
bieron atención prenatal en el sistema de salud pública en el Río de Janeiro, Brasil, de noviembre de 2007 hasta julio de 2008. Fueron entrevistadas 1.079 mujeres y la adecuación de aumento de peso se obtuvo mediante el cálculo de la cantidad de aumento de peso, recomendado por el Instituto de Medicina de los Estados Unidos. Factores sociodemográficos y obstétricos fueron analizados mediante regresión logística multinomial y las mujeres por debajo o por encima de las recomendaciones fueron comparadas con aquellas con suficiente aumento de peso. Un bajo nivel de educación se asoció con un aumento de peso insuficiente y un aumento excesivo de peso se observó entre las mujeres con presión arterial alta y un estado nutricional de bajo peso, sobrepeso y obesidad antes del embarazo. La evaluación nutricional durante la atención prenatal es esencial, y las intervenciones en salud deben dirigirse a los casos de aumento de peso inadecuado, con el fin de prevenir las complicaciones para la madre y el bebé.

Aumento de Peso; Embarazo; Mujeres Embarazadas; Estado Nutricional

\section{Conclusion}

The study showed different determinant factors for insufficient weight gain (lower schooling) and excessive gain (hypertension and pre-gestational nutritional status). These factors are easily identified in early pregnancy and are potential predictors of unfavorable outcomes.

The study found a particularly high proportion of pregnant women with pre-gestational overweight and obesity, corroborating other Brazilian and international studies. Considering that one of the goals of prenatal care is early identification of risk factors for unfavorable pregnancy outcomes, early prenatal care should focus greater attention on pregnant women with important nutritional deviations. Early identification and adequate referral favor timely and pertinent measures for each case, thereby minimizing the effects of inadequate pre-gestational weight.

\section{Contributors}

A. C. S. A. Fraga participated in the literature review, statistical analysis, and writing of the article. M. M. Theme Filha collaborated with the supervision, statistical analysis, and writing of the article.

\section{Acknowledgments}

The authors wish to thank researcher Fabio da Silva Gomes of the General Division for Prevention and Surveillance, Brazilian National Cancer Institute (INCA), and Professor Maria Elisa de Aquino Lacerda of Graduate Studies Program in Nutrition of the Josué de Castro Institute of Nutrition/UFRJ. The article is a development of the Master's thesis entitled Fatores Associados ao Ganho de Peso Gestacional em uma Amostra de Gestantes no Município do Rio de Janeiro, 2008 (ENSP/ Fiocruz; 2012), by A. C. S. A. Fraga. 
1. Institute of Medicine. Weight gain during pregnancy: reexamining the guidelines. Washington DC: National Academy Press; 2009.

2. Secretaria de Atenção à Saúde, Ministério da Saúde. Protocolos de Sistema de Vigilância Alimentar e Nutricional - SISVAN na assistência à saúde. Brasília: Ministério da Saúde; 2008.

3. Subcommittee for a Clinical Applications Guide, Institute of Medicine. Nutrition during pregnancy. Washington DC: National Academy Press; 1992.

4. Ronnenberg AG, Wang X, Xing H, Chen C, Chen $\mathrm{D}$, Guang W, et al. Low preconception body mass index is associated with birth outcome in a prospective cohort of Chinese women. J Nutr 2003; 133:3449-55.

5. Melo ASO, Assunção PL, Gondim SSR, Carvalho DF, Amorim MMR, Cardoso MAA. Estado nutricional materno, ganho de peso gestacional e peso ao nascer. Rev Bras Epidemiol 2007; 10:249-57.

6. Kac G. Fatores determinantes da retenção de peso no pós-parto: uma revisão da literatura. Cad Saúde Pública 2001; 17:455-66.

7. Nucci LB, Schmidt MI, Duncan BB, Fuchs SC, Fleck ET, Britto MMS. Nutritional status of pregnant women: prevalence and associated pregnancy outcomes. Rev Saúde Pública 2001; 35:502-7.

8. Scotland N, Hopkins L, Caughey A. Gestational weight gain, macrosomia, and risk of cesarean birth in nondiabetic nulliparas. Obstet Gynecol 2004; 104:671-7.

9. Rodrigues PL, Oliveira LC, Ados SB, Kac G. Determinant factors of insufficient and excessive gestational weight gain and maternal-child adverse outcomes. Nutrition 2010; 26:617-23.

10. Durie DE, Thornburg LL, Glantz JC. Effect of second-trimester and third-trimester rate of gestational weight gain on maternal and neonatal outcomes. Obstet Gynecol 2011; 118:569-75.

11. Hickey CA. Sociocultural and behavioral influences on weight gain during pregnancy. Am J Clin Nutr 2000; 71(5 Suppl):1364S-70S

12. Saunders C. Ajustes fisiológicos da gestação. In: Accioloy ESC, Lacerda EMA, organizadores. Nutrição em obstetrícia e pediatria. Rio de Janeiro: Editora Guanabara Koogan; 2009. p. 89-101.

13. Drehmer M, Camey S, Schmidt MI, Olinto MT, Giacomello A, Buss C, et al. Socioeconomic, demographic and nutritional factors associated with maternal weight gain in general practices in Southern Brazil. Cad Saúde Pública 2010; 26:1024-34.

14. Stulbach T, Benício M, Andrezza R, Kono S. Determinantes do ganho ponderal excessivo durante a gestação. Rev Bras Epidemiol 2007; 10:99-108.

15. Área Técnica de Saúde da Mulher, Departamento de Ações Programáticas Estratégicas, Secretaria de Atenção à Saúde, Ministério da Saúde. Pré-natal e puerpério: atenção qualificada e humanizada. Manual técnico. Brasília: Ministério da Saúde; 2006.

16. Marano D, Gama SG, Pereira AP, Souza Jr. PR. Adequação do ganho ponderal de gestantes em dois municípios do Estado do Rio de Janeiro (RJ), Brasil, 2008. Rev Bras Ginecol Obstet 2012; 34:386-93.
17. Leal MC, Gama SGN, Ratto KMN, Cunha CB. Uso do índice de Kotelchuck modificado na avaliação da assistência pré-natal e sua relação com as características maternas e o peso do recém-nascido no Município do Rio de Janeiro. Cad Saúde Pública 2004; 20 Suppl 1:S63-72.

18. Silva PLN. Crítica e imputação de dados quantitativos utilizando o SAS [Dissertação de Mestrado]. Rio de Janeiro: Instituto Nacional de Matemática Pura e Aplicada; 1988.

19. Saunders C, Accioly E, Costa RSS, Lacerda EMA, Santos MMAS. Gestante adolescente. In: Accioly ESC, Lacerda EMA, organizadores. Nutrição em obstetrícia e pediatria. Rio de Janeiro: Editora Guanabara Koogan; 2009. p. 151-74.

20. Ministério da Saúde. Programa de Humanização do Parto: humanização no pré-natal e nascimento. Manual técnico. Brasília: Ministério da Saúde; 2002.

21. Associação Brasileira de Empresas de Pesquisa. Critério de classificação econômica Brasil 2008. São Paulo: Associação Brasileira de Empresas de Pesquisa; 2008.

22. Centro Brasileiro de Análise e Planejamento, Ministério da Saúde. Pesquisa Nacional de Demografia e Saúde da Criança e da Mulher - PNDS 2006: dimensões do processo reprodutivo e da saúde da criança. Brasília: Ministério da Saúde; 2009.

23. Secretaria de Vigilância em Saúde, Ministério da Saúde. VIGITEL Brasil 2011: vigilância de fatores de risco e proteção para doenças crônicas por inquérito telefônico. Brasília: Ministério da Saúde; 2012. (Série G. Estatística e Informação em Saúde).

24. Nucci LB, Duncan BB, Mengue SS, Branchtein L, Schmidt MI, Fleck ET. Assessment of weight gain during pregnancy in general prenatal care services in Brazil. Cad Saúde Pública 2001; 17:1367-74.

25. Assunção P, Melo A, Gondim S, Benício M, Amorim M, Cardoso M. Ganho ponderal e desfechos gestacionais em mulheres atendidas pelo Programa de Saúde da Família em Campina Grande, PB, Brasil. Rev Bras Epidemiol 2007; 10:352-60.

26. Santos EM, Amorim LP, Costa OL, Oliveira N, Guimaraes AC. Perfil de risco gestacional e metabólico no serviço de pré-natal de maternidade pública do Nordeste do Brasil. Rev Bras Ginecol Obstet 2012; 34:102-6.

27. Monteiro C, Mondini L, Medeiros-de-Souza A, Popkin B. Da desnutrição para a obesidade: a transição nutricional no Brasil. In: Monteiro C, organizador. Velhos e novos males da saúde no Brasil: a evolução do país e suas doenças. 2ạ Ed. São Paulo: Editora Hucitec/Núcleo de Pesquisas Epidemiológicas em Nutrição e Saúde, Universidade de São Paulo; 2000. p. 247-55.

28. Seabra G, Padilha PC, Queiroz JA, Saunders C. Sobrepeso e obesidade pré-gestacionais: prevalência e desfechos associados à gestação. Rev Bras Ginecol Obstet 2011; 33:348-53. 
29. Bodnar L, Catov J, Klebanoff M, Ness R, Roberts J. Prepregnancy body mass index and the occurrence of severe hypertensive disorders of pregnancy. Epidemiology 2007; 18:234-9.

30. Padilha PC, Saunders C, Machado RCM, Silva CL, Bull A, Sally EOF, et al. Associação entre o estado nutricional pré-gestacional e a predição do risco de intercorrências gestacionais. Rev Bras Ginecol Obstet 2007; 29:511-8.

31. Konno SC, Benicio MHD’A, Barros AJ. Fatores associados à evolução ponderal de gestantes: uma análise multinível. Rev Saúde Pública 2007; 41:995-1002.

32. Coelho N. Associação entre padrões de consumo alimentar gestacional e peso ao nascer [Dissertação de Mestrado]. Rio de Janeiro: Escola Nacional de Saúde Pública Serio Arouca, Fundação Oswaldo Cruz; 2011.

33. Chu SY, Callaghan WM, Bish CL, D'Angelo D. Gestational weight gain by body mass index among US women delivering live births, 2004-2005: fueling future obesity. Am J Obstet Gynecol 2009; 200:271e1-7.

34. Domingues R, Hartz Z, Leal M. Avaliação das ações de controle da sífilis e do HIV na assistência prénatal da rede pública do município do Rio de Janeiro, Brasil. Rev Bras Saúde Matern Infant 2012; 12:269-80.
35. Vitolo MR, Bueno MS, Gama CM. Impacto de um programa de orientação dietética sobre a velocidade de ganho de peso de gestantes atendidas em unidades de saúde. Rev Bras Ginecol Obstet 2011; 33:13-9.

36. Barros DC, Saunders C. Diagnóstico nutricional de gestantes. In: Engstrom EM, organizador. SISVAN instrumento para o combate aos distúrbios nutricionais em serviços de saúde. 4a Ed. Rio de Janeiro: Fundação Oswaldo Cruz; 2009. p. 151-76.

37. Kac G, Velasquez-Melendez G. Ganho de peso gestacional e macrossomia em uma coorte de mães e filhos. J Pediatr (Rio J.) 2005; 81:47-53.

38. Brawarsky P, Stotland NE, Jackson RA, FuentesAfflick E, Escobar GJ, Rubashkin N, et al. Pre-pregnancy and pregnancy-related factors and the risk of excessive or inadequate gestational weight gain. Int J Gynaecol Obstet 2005; 91:125-31.

Submitted on 26/Apr/2013

Final version resubmitted on 16/Jul/2013

Approved on 29/Aug/2013 